\title{
Ceratocystis ulmi in Finland
}

\author{
V. Hintikka
}

Dutch Elm Disease occurs rather sporadically in Northern Europe, probably due to the rarity of elms as well as of the vector beetles. In Sweden the disease was found in 1950 (MATHIESEN-Kä̈̈RIK 1953), in Norway in 1963 (Heijbroek 1967) and in the Estonian SSR it has occurred since the 1930's (Parmasto 1961).

The causing fungus Ceratocystis ulmi (Buis.) C. Moreau was first discovered in Finland in the year 1963 by Dr. H. M. Heijbroek. He found the disease both from Turku and Helsinki. The diseased trees in Turku Keskikatu have been removed, and it seems that the disease is not spreading. $\mathrm{Al}$ so the trees in Helsinki in Tähtitorninmäki (Observationsberget) and in Vuorimiehenpuisto in which the disease was found in 1963, were removed in spring 1964, and the spread of the disease was checked. In the tree Tähtitorninmäki the disease was found to occur already in 1952 - 53, based on dark spots in corresponding annual ring. In neither tree Scolytes beetles were found when cut in 1964.

After these findings, two additional cases have been discovered. In Helsinki Teollisuuskatu, 1 one diseased elm was found in 1965. The tree was cut in February 1965, and also in this tree no signs of the presence of Scolytes beetles were found.

In 1968 a large diseased tree was discovered in Loviisa, situated in Sibeliuskatu ca. 50 meters from the railroad eastwards. The tree was removed in following year.

In all cases investigated the fungus caused considerable damage in the trees and up to half of the foliage was killed, and made them totally unsuited for ornamental purposes.

\section{REFERENCES}

Heijbroek, H. M. 1967: The Dutch elm disease in the Old World. - 14. IUfro Congr. München Sect. 24, 447-454.

MAthiesen-Kä̈̈RIK, A. 1953: Almsjukans utbredning i Sverige under åren 1950-1952. -
Skogen 40, 2-3, 11.

Parmasto, E. 1961: Metsas esinevad taimehaigused. - In: Maavara, V., Merihein, A. Parmas, H. and Parmasto, E. 1961: Metsäkaitse, pp. 333-452. - Tallinn. 